\title{
CMEARTICLE
}

\section{An approach to cervical lymphadenopathy in children}

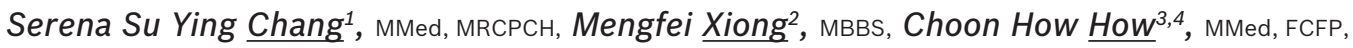
Dawn Meijuan $\underline{\text { Lee }^{1}}$, MBBS, MRCPCH

\begin{abstract}
Mrs Tan took her daughter Emma, a well-thrived three-year-old girl, to the family clinic for two days of fever, sore throat and rhinorrhoea. Apart from slight decreased appetite, Mrs Tan reported that Emma's activity level and behaviour were not affected. During the examination, Emma was interactive, her nose was congested with clear rhinorrhoea, and there was pharyngeal injection without exudates. You discovered bilateral non-tender, mobile cervical lymph nodes that were up to $1.5 \mathrm{~cm}$ in size. Mrs Tan was uncertain if they were present prior to her current illness. There was no organomegaly or other lymphadenopathy. You treated Emma for viral respiratory tract illness and made plans to review her in two weeks for her cervical lymphadenopathy.
\end{abstract}

\section{WHAT IS LYMPHADENOPATHY?}

Lymphadenopathy is defined as the presence of one or more lymph nodes of more than $1 \mathrm{~cm}$ in diameter, with or without an abnormality in character. ${ }^{(1)}$ In children, it represents the majority of causes of neck masses, which are abnormal palpable lumps or swellings.

\section{HOW RELEVANT IS THIS TO MY PRACTICE?}

Cervical lymphadenopathy in the paediatric population is common in general medical practice and presents either as a primary complaint of neck mass or as an incidental finding during clinical examination. Park reported that $90 \%$ of all children aged 4-8 years have palpable lymphadenopathy. ${ }^{(2)}$ In a systematic review of paediatric cervical lymphadenopathy involving 2,687 patients, two thirds of the cases were due to non-specific benign aetiology with no definitive diagnosis, and $4.7 \%$ were secondary to malignancy. ${ }^{(3)}$

When first reviewing a child with cervical lymphadenopathy, the primary care physician is faced with a conundrum - manage at primary care or refer for specialist review? We propose that the physician's familiarity with the differential diagnoses of lymphadenopathy and neck masses increases the success rate of managing this in primary care. An evidence-based evaluation framework may reduce unnecessary diagnostic tests and therapies, as well as enable physicians to counsel their patients and caregivers appropriately.

\section{WHAT CAN I DO IN MY PRACTICE? Clinical approach}

In the initial approach, it is important to first consider the broad differential diagnosis of cervical lymphadenopathy, including other causes of neck masses that may mimic it closely (Table I). ${ }^{(4)}$ Neck masses in children can be classified into congenital or acquired causes. Congenital lesions are usually painless and may be identified at or shortly after birth. They may also present with chronic drainage or recurrent episodes of swelling, which may only be obvious in later life or after a secondary infection. The location of the mass is often useful in narrowing down the diagnosis. Notably, midline masses are often not due to lymphadenopathy. The sternocleidomastoid muscle is used as an important surface landmark to distinguish between the anterior and posterior triangles of the neck.

A thorough history and physical examination are fundamental steps in the evaluation of a child with the complaint of a neck mass.

\section{History}

The following questions are important in evaluating for the various possible causes of neck masses in children:

- $\quad$ Patient's age

- Duration of neck mass: (a) present since birth or recently discovered, and for how long; and (b) recurrence of neck mass

- Associated symptoms: (a) focal symptoms (e.g. pain, erythema); (b) infective symptoms (e.g. fever, sore throat, other localising symptoms of infection); (c) rashes, arthralgia and other features of Kawasaki disease (KD), including conjunctival injection, erythema/cracking of lips and tongue, and erythema/swelling of hands and feet; and (d) weight loss, loss of appetite, night sweats, fatigue, easy bruising and pallor

- Recent illnesses (e.g. pharyngitis, tonsillitis, dental infections)

- History of recurrent infections, recurrent skin abscesses or recurrent lymphadenopathy

- Drug history, including any treatment with antibiotics

- Exposure to animals (particularly cats), insects, sick persons, persons with tuberculosis or chronic cough

- Recent travel history

- Immunisation status

${ }^{1}$ Department of Paediatric Medicine, KK Women's and Children's Hospital, ${ }^{2}$ Resident, Family Medicine Programme, SingHealth Residency, ${ }^{3} \mathrm{C} a r e$ and Health Integration, Changi General Hospital, ${ }^{4}$ Family Medicine Academic Clinical Programme, SingHealth Duke-NUS Academic Medical Centre, Singapore 
Table I. Differential diagnoses of neck masses.

\begin{tabular}{|c|c|c|}
\hline Location & Congenital & Acquired \\
\hline $\begin{array}{l}\text { Anterior } \\
\text { midline or } \\
\text { paramedian }\end{array}$ & $\begin{array}{l}\text { - Thyroglossal cyst } \\
\text { - Dermoid cyst } \\
\text { - Thymic cyst }\end{array}$ & $\begin{array}{l}\text { - Thyroid lesions: goitre, } \\
\text { thyroiditis, rarely thyroid } \\
\text { cancer }\end{array}$ \\
\hline $\begin{array}{l}\text { Anterior } \\
\text { triangle }\end{array}$ & $\begin{array}{l}\text { - Branchial cleft } \\
\text { anomalies } \\
\text { - Congenital } \\
\text { muscular torticollis } \\
\text { - Vascular lesions } \\
\text { (haemangioma, } \\
\text { lymphangioma) } \\
\text { - Cervical rib }\end{array}$ & $\begin{array}{l}\text { - Lymphadenopathy } \\
\text { - Submandibular gland } \\
\text { enlargement (e.g. } \\
\text { sialadenitis, sialolithiasis, } \\
\text { rarely neoplasm) } \\
\text { - Epidermoid cyst }\end{array}$ \\
\hline $\begin{array}{l}\text { Angle of the } \\
\text { mandible }\end{array}$ & - & $\begin{array}{l}\text { Parotid gland enlargement } \\
\text { (e.g. acute or recurrent } \\
\text { parotitis, sialolithiasis, rarely } \\
\text { neoplasm) }\end{array}$ \\
\hline $\begin{array}{l}\text { Posterior } \\
\text { triangle }\end{array}$ & Cystic hygroma & $\begin{array}{l}\text { - Lymphadenopathy } \\
\text { - Epidermoid cyst } \\
\text { - Malignant neoplasm } \\
\text { (e.g. rhabdomyosarcoma, } \\
\text { neuroblastoma) }\end{array}$ \\
\hline
\end{tabular}

\section{Physical examination}

A complete physical examination always includes a general inspection of the child's growth parameters (i.e. growth charts) and general health status. The presence of pallor or jaundice should be determined. In addition to the location of the neck mass, it is important to examine the following:

- $\quad$ Size of lesion

- Quality of lesion: (a) tenderness, warmth, mobility, fluctuance, consistency and erythema; and (b) other overlying skin changes such as cutaneous sinus tract

- A sequential examination of the lymph node chains of the head and neck (Fig. 1) should be performed. If cervical lymphadenopathy is suspected, other areas of peripheral lymphadenopathy should also be palpated (i.e. axillary, epitrochlear, inguinal, popliteal) to determine if the lymphadenopathy is localised or generalised. Of note, the finding of an enlarged lymph node in the supraclavicular region is concerning, as it may be associated with an underlying malignancy.

- A quick examination of the eyes, ears, nose, mouth and throat should be performed to look for common sources of infection that could cause cervical lymphadenopathy (Table II).

- To complete the examination, assess for the presence of rashes, KD features, petechiae/purpura and joint swelling, and palpate the abdomen to assess for hepatosplenomegaly or abdominal masses. Table III shows some of the more commonly seen congenital neck masses, with characteristic features that may aid in their diagnosis. ${ }^{(4)}$

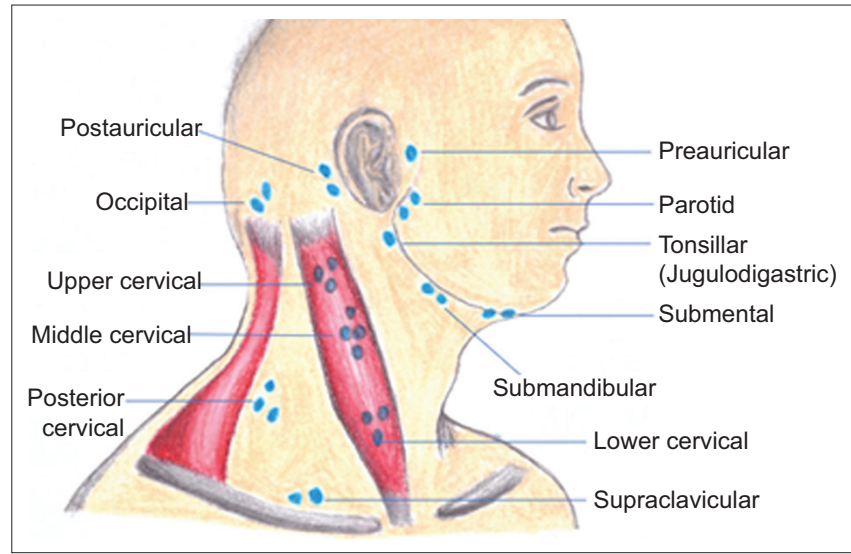

Fig. 1 Illustration shows an overview of the lymph node regions of the neck (reproduced with permission from Dr Marc Ong Weijie).

Table II. Summary of drainage areas for cervical lymph node groups.

\begin{tabular}{|ll|}
\hline Region & Drainage areas \\
\hline Submental & Bottom lip, floor of mouth, skin of cheeks \\
\hline Submandibular & $\begin{array}{l}\text { Mouth, lips, tongue, submandibular gland, } \\
\text { cheek }\end{array}$ \\
\hline Preauricular & $\begin{array}{l}\text { Anterior and temporal scalp, anterior ear } \\
\text { canal and pinna, conjunctiva, parotids }\end{array}$ \\
\hline Postauricular & Temporal and parietal scalp \\
\hline Occipital & Posterior scalp \\
\hline $\begin{array}{l}\text { Upper, middle and } \\
\text { lower cervical }\end{array}$ & $\begin{array}{l}\text { Tongue, tonsils, larynx, oropharynx, anterior } \\
\text { neck, scalp, lower ear canal, parotid }\end{array}$ \\
\hline Posterior cervical & Scalp and neck \\
\hline Supraclavicular & Mediastinum, lungs, abdomen \\
\hline
\end{tabular}

\section{WHAT ARE THE MAIN CAUSES?}

In a child with cervical lymphadenopathy, the duration of lymphadenopathy is a key consideration in determining its possible aetiology, which can be categorised into four main groups: infectious, immunologic, malignancy and miscellaneous causes. The causes can then be classified according to the origin and time course of symptoms, as presented in Table IV. ${ }^{(5,6)}$

\section{Acute cervical lymphadenopathy Infective causes}

The most common scenario of acute cervical lymphadenopathy is enlargement of bilateral lymph nodes in the correct nodal drainage chain during an acute infection. This represents a selflimiting, transient response of lymphatic tissue hyperplasia to a local infective process that improves with resolution of the viral illness. In the absence of red flags, it can be managed according to Fig. 2. The use of systemic antibiotics is often not warranted.

Ebstein-Barr virus (EBV) and cytomegalovirus (CMV) infections may be more common in older children of school-going age and adolescents. Children with EBV infection often present with a clinical picture of infectious mononucleosis, characterised by generalised lymphadenopathy, sore throat, fatigue and fever. This may be accompanied by exudative tonsillitis and hepatosplenomegaly. 
Table III. Common congenital neck masses.

\begin{tabular}{|c|c|c|}
\hline Neck mass & Characteristics & Common age of presentation \\
\hline Thyroglossal duct cysts & $\begin{array}{l}\text { - Most common congenital neck mass } \\
\text { - Moves up with tongue protrusion }\end{array}$ & $2-10$ years \\
\hline $\begin{array}{l}\text { Branchial cleft } \\
\text { anomalies }\end{array}$ & $\begin{array}{l}\text { - Second most common congenital neck mass } \\
\text { - Includes cysts, sinuses and fistulas } \\
\text { - Manifests as presence of pit, dimple, sinus or mass along anterior margin } \\
\text { of sternocleidomastoid muscle }\end{array}$ & $\begin{array}{l}\text { Fistulas: infancy } \\
\text { Cysts: older children }>10 \text { years but } \\
\text { can present at any age }\end{array}$ \\
\hline Cystic hygroma & $\begin{array}{l}\text { - Soft, painless, fluctuant masses with violaceous appearance } \\
\text { - Transilluminable }\end{array}$ & Birth to 2 years \\
\hline Dermoid cysts & $\begin{array}{l}\text { - Midline lesions that do not move up on swallowing or tongue protrusion } \\
\text { - Rubbery consistency, attached to overlying skin }\end{array}$ & Aged $<5$ years \\
\hline $\begin{array}{l}\text { Congenital muscular } \\
\text { torticollis }\end{array}$ & $\begin{array}{l}\text { - Firm, fibrous mass within belly of sternocleidomastoid muscle } \\
\text { - Causes torticollis and positional plagiocephaly }\end{array}$ & Birth to first few weeks of life \\
\hline Infantile haemangioma & $\begin{array}{l}\text { - Flat purplish lesions at birth } \\
\text { - Enlarge in first year of life - soft, compressible, red or purple masses, not } \\
\text { transilluminable } \\
\text { - Spontaneous involution thereafter }\end{array}$ & Birth \\
\hline
\end{tabular}

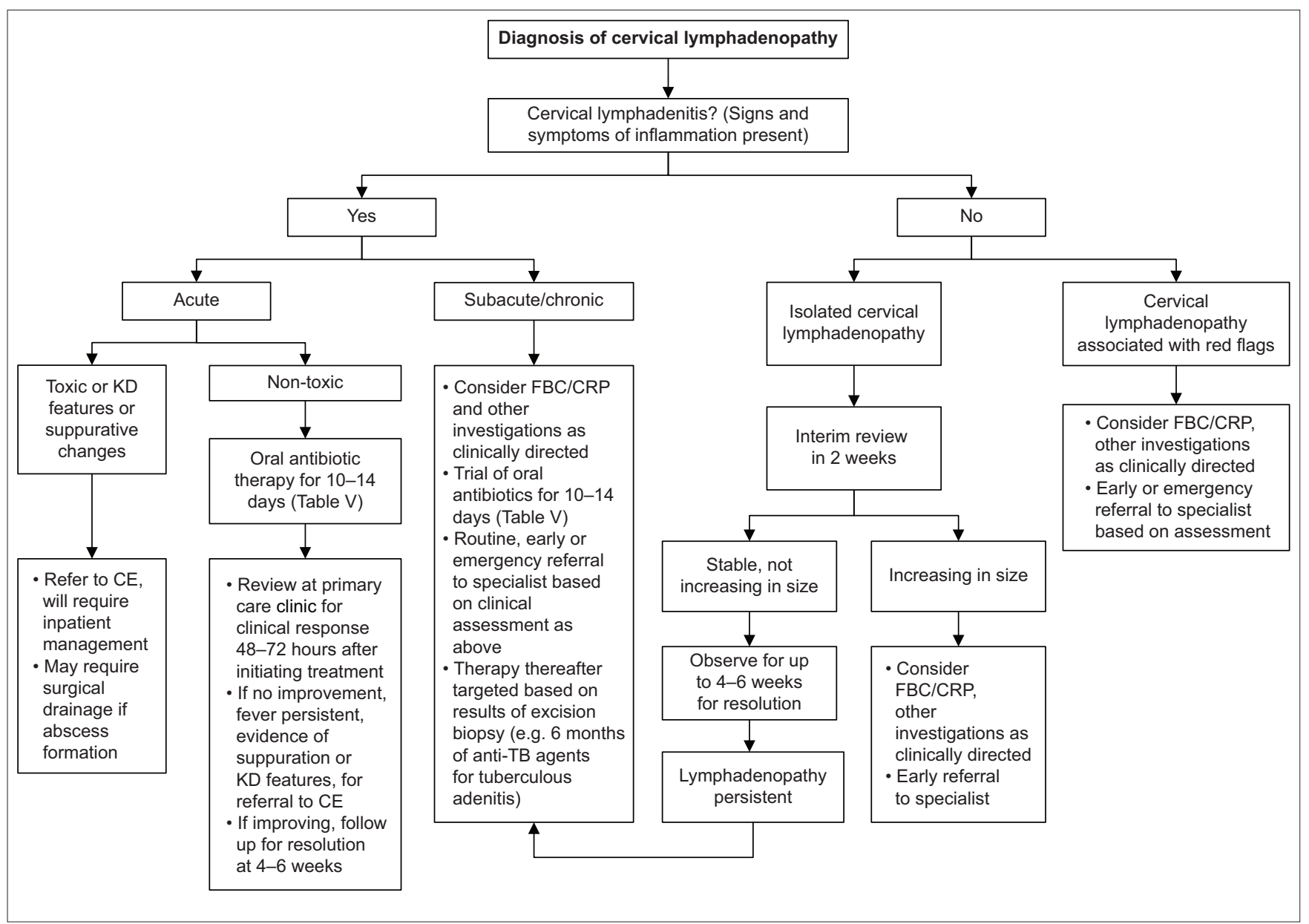

Fig. 2 Flowchart summarises the general principles for the management of cervical lymphadenopathy. CE: children's emergency department; CRP: C-reactive protein; FBC: full blood count; KD: Kawasaki disease; TB: tuberculosis

Children can also present with acute unilateral cervical lymphadenitis, caused by bacterial infection. Lymphadenitis is defined as lymphadenopathies caused by an inflammatory process, resulting in enlarged, tender lymph nodes with or without overlying erythema. ${ }^{(6)}$ The most common causative pathogens are Staphylococcus aureus or Streptococcus pyogenes
(Group A Streptococcus). ${ }^{(5)}$ The primary source of infection may or may not be found. Acute unilateral cervical lymphadenitis most often affects children aged 1-4 years. Some may progress to have abscess formation. Less commonly, it may be caused by anaerobic bacteria associated with dental infections and abscesses. 
Table IV. Causes of cervical lymphadenopathy.

\begin{tabular}{|c|c|c|}
\hline Duration & Aetiologies & Associated clinical features \\
\hline \multirow{12}{*}{$\begin{array}{l}\text { Acute } \\
(<2 \text { weeks })\end{array}$} & Infections (more common) & \\
\hline & Frequently occurring: & \\
\hline & $\begin{array}{l}\text {-Viral infections - respiratory viruses } \\
\text { (adenovirus, influenza virus and respiratory } \\
\text { syncytial virus etc) }\end{array}$ & $\begin{array}{l}\text { Bilateral cervical lymphadenopathy, upper respiratory tract infection } \\
\text { symptoms }\end{array}$ \\
\hline & - EBV and CMV & $\begin{array}{l}\text { EBV - fever, lethargy, sore throat, exudative tonsillitis, } \\
\text { hepatosplenomegaly }\end{array}$ \\
\hline & $\begin{array}{l}\text { - Bacterial infections - Staphylococcus aureus, } \\
\text { Group A Streptococcus }\end{array}$ & Unilateral, tender lymphadenopathy, overlying erythema, fever \\
\hline & Infrequently occurring: & \\
\hline & - Group B Streptococcus & Neonatal/infant age group \\
\hline & - Anaerobic bacteria & Oral mucositis, dental caries or infections \\
\hline & Immunologic (less common) & \\
\hline & - Kawasaki disease & $\begin{array}{l}\text { Fever, rash, red lips, strawberry tongue, unilateral cervical } \\
\text { lymphadenopathy, swollen or erythematous hands or feet, BCG } \\
\text { vaccination scar erythema or induration }\end{array}$ \\
\hline & - Kikuchi-Fujimoto disease & $\begin{array}{l}\text { Prolonged, unexplained fever, chills, weight loss, night sweats, rash and } \\
\text { arthralgia }\end{array}$ \\
\hline & $\begin{array}{l}\text { Miscellaneous (less common) } \\
\text { - Adverse drug reaction } \\
\text { - Histiocytosis }\end{array}$ & \\
\hline \multirow{9}{*}{$\begin{array}{l}\text { Subacute to } \\
\text { chronic } \\
\text { ( } 2-6 \text { weeks) }\end{array}$} & Infections (more common) & \\
\hline & Frequently occurring: & \\
\hline & - Non-tuberculous mycobacterium & $\begin{array}{l}\text { Unilateral, usually multiple, firm lymph nodes; thin and violaceous } \\
\text { overlying skin. May develop fluctuance or cutaneous sinus tracts }\end{array}$ \\
\hline & • EBV, CMV & As above \\
\hline & Infrequently occurring: & \\
\hline & - Mycobacterium tuberculosis & $\begin{array}{l}\text { Unilateral or bilateral, firm, non-tender lymph nodes; may be fixed to } \\
\text { underlying tissues and progress to become matted, low-grade fever } \\
\text { with systemic symptoms }\end{array}$ \\
\hline & - Bartonella henselae (cat-scratch disease) & Cat scratch or bite \\
\hline & $\begin{array}{l}\cdot \text { HIV } \\
\text { - Fungal or protozoan infection (e.g. } \\
\text { toxoplasmosis, malaria) }\end{array}$ & \\
\hline & $\begin{array}{l}\text { Immunologic (less common) } \\
\text { - Systemic lupus erythematosus } \\
\text { - Juvenile idiopathic arthritis } \\
\text { - Dermatomyositis }\end{array}$ & $\begin{array}{l}\text { Generalised non-tender lymphadenopathy, fever, rash, arthralgia, } \\
\text { arthritis, hepatosplenomegaly }\end{array}$ \\
\hline \multirow{6}{*}{$\begin{array}{l}\text { Chronic } \\
\text { (>6 weeks) }\end{array}$} & Malignancies (more common) & \\
\hline & $\begin{array}{l}\text { - Hodgkin's and non-Hodgkin's lymphoma } \\
\text { - Acute leukaemia } \\
\text { - Rhabdomyosarcoma } \\
\text { - Neuroblastoma }\end{array}$ & $\begin{array}{l}\text { Firm, indurated, fixed, matted, usually non-tender lymph nodes; } \\
\text { supraclavicular lymph nodes; systemic symptoms; petechiae; pallor; } \\
\text { hepatosplenomegaly }\end{array}$ \\
\hline & Immunologic (less common) & \\
\hline & - Common variable immunodeficiency & \\
\hline & $\begin{array}{l}\text { - Chronic granulomatous disease } \\
\text { • Hyper-immunoglobulin E syndrome }\end{array}$ & \\
\hline & $\begin{array}{l}\text { Miscellaneous (less common) } \\
\text { - Sarcoidosis } \\
\text { - Storage disease (Gaucher disease, Niemann- } \\
\text { Pick disease) }\end{array}$ & \\
\hline
\end{tabular}

BCG: Bacillus Calmette-Guérin; CMV: cytomegalovirus; EBV: Ebstein-Barr virus 
An important distinguishing feature between viral and bacterial lymphadenitis is whether there is self-resolution. Primary bacterial lymphadenitis or a viral lymphadenitis with secondary bacterial infection should be considered if the patient does not improve after 4-7 days.

\section{Immunologic causes}

Kawasaki disease

$\mathrm{KD}$ is the most common childhood acute vasculitic disease of unclear aetiology and is associated with the development of coronary artery complications. It mainly affects children under five years of age. The diagnosis is clinical, based on the presence of fever lasting five days or more, and a constellation of symptoms, which may not all be present. These include polymorphous exanthem, bilateral non-suppurative conjunctivitis, changes in lips and oral mucosa, changes in extremities, and usually unilateral cervical lymphadenopathy measuring more than $1.5 \mathrm{~cm}$. KD should be considered in a child with persistent fever and cervical lymphadenitis despite the use of antibiotics.

Most reports in the literature describe KD as an uncommon cause of cervical lymphadenopathy, with the highest incidence in Asian countries, in particular Japan, South Korea and Taiwan. ${ }^{(7)}$ However, in the wake of the current coronavirus 2019 (COVID-19) pandemic, there has been increasing interest in KD in European countries with large COVID-19 outbreaks. These countries have reported cases of a paediatric multi-system inflammatory syndrome, where critically ill children present with features of shock and Kawasaki-like disease, which may be temporally associated with COVID-19 infection. ${ }^{(8)}$ Although Singapore has not yet seen such cases among the paediatric population, the Ministry of Health has issued an advisory for medical practitioners to be aware of this condition. This further highlights the importance of early recognition of KD at a primary care level, to facilitate early specialist referral.

\section{Kikuchi-Fujimoto disease}

Kikuchi-Fujimoto disease, also known as histiocytic necrotising lymphadenitis, is a lesser known clinical entity but is not as uncommon as previously perceived. It usually presents in older children and adolescents, most commonly aged 7-12 years, with unexplained fever and cervical lymphadenopathy. Accompanying symptoms include weight loss, night sweats, chills, rash and arthralgia. Although generally understood to be a self-limiting, benign condition of unknown aetiology, it can lead to significant complications including aseptic meningitis, with reports of progression to systemic lupus erythematosus. ${ }^{(9}$ A biopsy of the lymph node is required for histopathological diagnosis.

\section{Miscellaneous}

Less commonly, lymphadenopathy can be a result of an adverse drug reaction. Medications that may cause this include phenytoin, isoniazid, pyrimethamine and allopurinol.

\section{Subacute or chronic cervical lymphadenopathy Chronic infective causes}

Atypical mycobacterial, or non-tuberculous mycobacterial (NTM) infection, often affects children aged $1-5$ years. It is the most common cause of chronic cervical lymphadenopathy. Children with NTM infection present with progressive lymph node enlargement over weeks to months, although the onset may also be acute and very rapid. They are often afebrile and have unilateral, non-tender lymphadenitis, with thin and violaceous overlying skin. It commonly affects the upper anterior cervical and submandibular lymph nodes. ${ }^{(10)}$ The affected lymph nodes may undergo rapid suppuration or rupture and form sinus tracts.

Mycobacterium tuberculosis infection is less common. It can affect all age groups, but usually older children above five years of age. It can cause unilateral or bilateral, firm, discrete, non-tender lymphadenopathy, often fixed to underlying tissues. There may be associated low-grade fever and systemic symptoms. There is usually a preceding history of exposure to tuberculosis, and $28 \%-$ $71 \%$ of affected patients have abnormal chest radiographs. ${ }^{(10)}$

Bartonella henselae infection (cat-scratch disease) causes a granulomatous infection that is transmitted by the scratch or bite of a cat. ${ }^{(4)}$ Lymphadenopathy usually occurs after several weeks but can occur acutely as well.

\section{Malignancy}

Chronic cervical lymphadenopathy may be a presenting sign of a primary malignancy, or metastatic disease. The most common malignancies associated with cervical lymphadenopathy in the first six years of life are acute leukaemia, neuroblastoma, rhabdomyosarcoma and non-Hodgkin's lymphoma. Thereafter, after six years of age, Hodgkin's lymphoma is the most common malignancy, followed by non-Hodgkin's lymphoma and rhabdomyosarcoma. ${ }^{(11)}$ Worrying features include firm, indurated, fixed and matted lymph nodes that are usually not tender.

\section{Immunologic}

Autoimmune diseases, such as systemic lupus erythematosus, juvenile idiopathic arthritis and dermatomyositis, can cause chronic generalised lymphadenopathy. Lymph nodes are often non-tender and discrete, with a range of sizes from very small to a few centimetres in diameter. ${ }^{(6)}$

\section{WHAT INVESTIGATIONS SHOULD BE UNDERTAKEN?}

Investigations are necessary when cervical lymphadenopathy is subacute or chronic in presentation, has associated red flag features (Box 1), or if the child does not respond to appropriate first-line treatment. ${ }^{(5,12,13)}$

\section{In primary care}

The following are preliminary investigations that can be done in the primary care setting to aid in diagnostic and subsequent management decisions. These tests are especially valuable in cases that are routinely referred to tertiary care, and can further 
Box 1. Red flags in cases of cervical lymphadenopathy:

- Lymphadenopathy $>2 \mathrm{~cm}$

- Steady increase in size over 2-3 weeks

- No improvement or decrease in size after 4-6 weeks

- Supraclavicular lymphadenopathy

- Hard, fixed, matted, non-tender lymphadenopathy

- Persistent fever lasting more than one week

- Signs and symptoms suggestive of malignancy: weight loss,

petechiae, pallor, night sweats, hepatosplenomegaly

- Signs and symptoms suggestive of autoimmune disease: rash

arthralgia, arthritis, generalised lymphadenopathy

- Features suggestive of Kawasaki disease

- Abnormalities in full blood count or chest radiography

assure the patient and their family if their results are deemed normal. Conversely, abnormalities in these investigations would prompt a more urgent referral. In cases where emergency referral is felt to be necessary or investigations are difficult to perform, testing can also be performed by the tertiary paediatric institution.

\section{Blood investigations}

Full blood count (FBC) and peripheral blood film (PBF) should be done. Raised total white cell count and neutrophilia are suggestive of a bacterial aetiology, whereas cytopenia can be seen in viral aetiologies, haematological malignancies or autoimmune conditions. Thrombocytosis might be present in cases of reactive cervical lymphadenitis or inflammatory conditions such as KD. It is important to note the differential white cell counts, as lymphopenia can be seen in systemic lupus erythematosus, and a high percentage of atypical lymphocytes or monocytes can be seen in infectious mononucleosis syndrome. The PBF might reveal the presence of blast cells in cases of haematological malignancies.

Erythrocyte sedimentation rate (ESR) and C-reactive protein (CRP) levels are inflammatory markers that may be raised in infective (more likely from a bacterial cause) or inflammatory causes of cervical lymphadenopathy. However, for an inflammatory condition, a markedly raised ESR in relation to the CRP level would be more concerning.

Uric acid and lactate dehydrogenase (LDH) levels should also be checked. Raised uric acid and LDH levels are indicative of a high cell turnover state, and significantly raised levels are worrisome for an underlying malignancy. Liver function test (LFT) and renal panel are useful for determining multi-systemic involvement from the underlying condition.

The choice of blood tests is directed largely by clinical suspicion after assessment of the child. For example, if there are some features suggestive of malignancy, appropriate investigations would include FBC, PBF, and LDH and uric acid tests, while if there is a suspicion of autoimmune disease, FBC, CRP, ESR, LFT and renal panel tests would be appropriate. We propose that $\mathrm{FBC}$ and CRP tests are appropriate first-line blood investigations that can be performed, with other tests as clinically directed.

\section{Imaging}

Chest radiography is a helpful test to assess for evidence of mediastinal widening for cases of chronic lymphadenopathy, especially when malignancy such as lymphoma cannot be ruled out. Mediastinal widening may be suggestive of a mediastinal mass, or hilar adenopathy. This would be an indication for immediate emergency referral. It should also be performed in patients with a clinical suspicion of tuberculosis.

\section{In tertiary institutions}

\section{Specific serologic and antibody tests}

Specific serologic tests for EBV, CMV, Bartonella henselae and toxoplasmosis might be considered. The blood plasma anti-streptolysin $\mathrm{O}$ titre test can be used in the diagnosis of a streptococcal infection.

\section{Imaging}

Ultrasonography is advocated as the initial imaging modality for cervical lymphadenopathy, if required. It is useful in determining if complications such as an abscess formation have occurred, and can also be used to guide surgical drainage in such cases. It is also useful to differentiate lymphadenopathy from other causes of congenital or acquired neck masses. Other advantages of ultrasonography include lack of radiation exposure, easy availability, fast interpretation and lower cost compared to crosssectional imaging. The disadvantage of ultrasonography is that it is operator dependent.

Computed tomography $(\mathrm{CT})$ or magnetic resonance (MR) imaging investigations are particularly useful in evaluating neck masses located within the deep neck. Advantages of CT over MR imaging are that it is more readily available, has lower cost and has faster scan times. MR imaging is the imaging modality of choice to evaluate paediatric neck masses with suspected intracranial or intraspinal extension, and its significant advantage would be the lack of radiation exposure. However, sedation is usually required during MR imaging.

\section{Diagnostic biopsy}

The gold standard for tissue diagnosis is an excisional biopsy. There are several indications for which an excisional biopsy may be considered: ${ }^{(5,6,14)}$ (a) persistent or progressive lymphadenopathy after 4-6 weeks; (b) lymph nodes greater than $2 \mathrm{~cm}$; (c) symptoms and signs suggestive of malignancy; (d) supraclavicular lymph node; (e) unexplained, prolonged fever; (f) abnormal FBC (in particular cell line defects) or chest radiography; and (g) concerning features on ultrasonography or CT.

When indicated, the largest and most abnormal lymph node should be excised. ${ }^{(6)}$ The biopsy specimen can be sent for histology, gram stain and bacterial culture, acid-fast bacilli (AFB) smear and culture, AFB polymerase chain reaction test, fungal smear and fungal culture. If there is a suspicion of lymphoma, an excision biopsy should be performed with a pathologist on standby so that a fresh specimen can be sent for appropriate staining.

\section{WHAT ARE THE PRINCIPLES OF MANAGEMENT IN PRIMARY CARE?}

Management of cervical lymphadenopathy in children should be targeted at the underlying aetiology. Most cases of reactive 
Table V. Recommended antimicrobial therapy for acute cervical lymphadenitis.

\begin{tabular}{|llll|}
\hline Suspected organisms & First-line therapy & Alternative therapy (if penicillin allergy) & Duration \\
\cline { 1 - 2 } $\begin{array}{l}\text { Group A streptococci, } \\
\text { Staphylococcus aureus, } \\
\text { Haemophilus influenzae }\end{array}$ & Oral Augmentin $50 \mathrm{mg} / \mathrm{kg} /$ day Q12H & Oral clindamycin $30 \mathrm{mg} / \mathrm{kg} /$ day Q8H & $10-14$ days total \\
Anaerobic bacteria & OR oral cloxacillin $50 \mathrm{mg} / \mathrm{kg} /$ day Q6H & & $\begin{array}{l}\text { duration (until symptom } \\
\text { resolution) }\end{array}$ \\
\hline
\end{tabular}

Q6H: every six hours; Q8H: every eight hours; $\mathrm{Q} 12 \mathrm{H}$ : every 12 hours

cervical lymphadenopathy present with isolated bilateral, mobile, small sub-centimetre lymphadenopathy in response to a self-limiting viral illness, and reassurance by the primary care provider is often sufficient. In cases of isolated cervical lymphadenopathy of 1-2 cm with no other red flag features, patients should be followed up for 4-6 weeks until the swelling of the lymph nodes has resolved, ${ }^{(6,14)}$ with an interim follow-up at two weeks where feasible to ensure that there is no significant increase in size.

For acute non-toxic cervical lymphadenitis, patients can be reviewed 48-72 hours after starting oral antibiotics; lack of improvement, persistence of fever, evidence of suppurative changes or development of KD features should prompt emergency referral.

\section{WHEN SHOULD I REFER TO A SPECIALIST?}

Children with red flags based on history and physical examination (Box 1) that suggest more worrisome underlying disease ${ }^{(5,6,10,12)}$ warrant further investigations and referral for specialist assessment. As a general guide, these patients can be referred to paediatric medicine, or to the ear, nose and throat department for cases that may benefit from biopsy or when congenital neck masses are suspected. For children who appear unwell and present with features suggestive of bacterial lymphadenitis, especially in infants and toddlers for whom a thorough clinical assessment might be more challenging, an emergency referral to a tertiary paediatric hospital would be necessary for initiation of early intravenous antibiotics.

The timeliness of referral largely depends on the physician's discretion, based on clinical assessment. We propose the following timelines as a guide:

- $\quad$ Routine referral (seen within 4-6 weeks) for persistent isolated lymphadenopathy $<2 \mathrm{~cm}$ not improving after 4-6 weeks with no other red flag features

- $\quad$ Early referral (seen within 2-3 weeks) for lymphadenopathy $>2 \mathrm{~cm}$, steady increase in size during observation, signs and symptoms suggestive of autoimmune disease

- Emergency referral for toxic cervical lymphadenitis, or acute cervical lymphadenitis with no improvement 48-72 hours after starting oral antibiotic therapy, features of $\mathrm{KD}$, associated persistent fever $>5$ days, evidence of suppuration, signs and symptoms strongly suggestive of malignancy, chest radiography changes (e.g. mediastinal widening), or significant laboratory test abnormalities.
Fig. 2 summarises the general management principles. Table $\mathrm{V}$ summarises the recommended antibiotic regimens used for treatment of acute cervical lymphadenitis in well, non-toxic children in the primary care setting, ${ }^{(11,15)}$ which are targeted at the most likely causative organisms Staphylococcus aureus or Streptococcus pyogenes.

\section{TAKE HOME MESSAGES}

1. Cervical lymphadenopathy is a common problem in children, with reactive lymphadenopathy from a variety of viral infections being the most common cause. In these instances, systemic antibiotics are not warranted.

2. Features suggestive of cervical lymphadenitis secondary to bacterial infection include an acute presentation, fever, and prominent tenderness in the lymph nodes with or without overlying erythema. The primary source of infection may or may not be found. In these cases, empiric antibiotic therapy should be directed towards treating the most likely causative organisms, Staphylococcus aureus or Streptococcus pyogenes.

3. The primary care practitioner should evaluate for red flags that would prompt early investigations and need for specialist referral. Congenital neck masses, such as branchial cleft anomalies, may mimic lymphadenopathy and must be considered.

4. The choice of investigations is largely directed by clinical suspicion after assessment of the child. Investigations should be performed in cases of subacute or chronic lymphadenopathy, when there are associated red flags or if the child does not respond to first-line treatment. First-line investigations are FBC and CRP tests, with other tests as clinically indicated, to evaluate for more worrisome pathology.

5. An excisional biopsy of the cervical lymph node is the gold standard test for tissue diagnosis.

6. In children with acute cervical lymphadenitis, a timely reevaluation should always be done to examine their clinical response to appropriate first-line oral antibiotics. Failure of first-line therapy should prompt the primary care provider to consider other differentials, particularly KD, for which early diagnosis is important to facilitate urgent paediatric referral and initiate appropriate, time-sensitive treatment.

7. Early intravenous antibiotics are needed in a child who looks unwell and presents with features suggestive of bacterial lymphadenitis, especially in infants and toddlers, for whom a thorough clinical assessment might be more challenging. 
At her follow-up visit two weeks later, Emma had recovered fully from her recent infection and was well. As her cervical lymph nodes were stable, you planned to observe her and follow up in another four weeks. However, at the second follow-up visit, she still had non-tender, mobile cervical lymph nodes that were $2 \mathrm{~cm}$ in size. You ordered a full blood count and C-reactive protein test for her, which came back normal. In the absence of additional red flags, you decided to refer Emma to a paediatrician for further evaluation of persistent cervical lymphadenopathy.

\section{REFERENCES}

1. Ferrer R. Lymphadenopathy: differential diagnosis and evaluation. Am Fam Physician 1998; 58:1313-20.

2. Park YW. Evaluation of neck masses in children. Am Fam Physician 1995; 51:1904-12.

3. Deosthali A, Donches K, DelVecchio M, Aronoff S. Etiologies of pediatric cervical lymphadenopathy: a systematic review of 2687 subjects. Glob Pediatr Health 2019; 6:2333794X19865440.

4. Jackson DL. Evaluation and management of pediatric neck masses. Physician Assist Clin 2018; 3:245-69.

5. Weinstock MS, Patel NA, Smith LP. Pediatric cervical lymphadenopathy. Pediatr Rev 2018; 39:433-43.

6. Friedmann AM. Evaluation and management of lymphadenopathy in children. Pediatr Rev 2008; 29:53-60.

7. Lin MT, Wu MH. The global epidemiology of Kawasaki disease: Review and future perspectives. Glob Cardiol Sci Pract 2017; 2017:e201720.

8. Viner RM, Whittaker E. Kawasaki-like disease: emerging complication during the COVID-19 pandemic. Lancet 2020; 395:1741-3.

9. Selvanathan SN, Suhumaran S, Sahu VK, Chong CY, Tan NWH, Thoon KC. Kikuchi-Fujimoto disease in children. J Paediatr Child Health 2020; 56:389-93.

10. Rosenberg TL, Nolder AR. Pediatric cervical lymphadenopathy. Otolaryngol Clin North Am 2014; 47:721-31.

11. Leung AK, Robson WL. Childhood cervical lymphadenopathy. J Pediatr Health Care 2004; 18:3-7.

12. Lang S, Kansy B. Cervical lymph node diseases in children. GMS Curr Top Otorhinolaryngol Head Neck Surg 2014; 13:Doc08.

13. Rajasekaran K, Krakovitz P. Enlarged neck lymph nodes in children. Pediatr Clin North Am 2013; 60:923-36.

14. Locke R, Comfort R, Kubba H. When does an enlarged cervical lymph node in a child need excision? A systematic review. Int J Pediatr Otorhinolaryngol 2014; 78:393-401.

15. Gosche JR, Vick L. Acute, subacute, and chronic cervical lymphadenitis in children. Semin Pediatr Surg 2006; 15:99-106. 


\section{SINGAPORE MEDICAL COUNCIL CATEGORY 3B CME PROGRAMME} (Code SMJ 202011A)

1. Lymphadenopathy is defined as having one or more lymph nodes that are more than $0.5 \mathrm{~cm}$ in diameter, with or without an abnormality in character.

2. It is important to perform an examination of the eyes, ears, nose, mouth and throat in the evaluation of a child with cervical lymphadenopathy.

3. Congenital neck masses may present later in life with chronic drainage or recurrent episodes of swelling after secondary infection.

4. Branchial cleft anomalies are the most common cause of congenital neck mass.

5. Infective causes, in particular reactive lymphadenopathy secondary to viral infection, comprise the most common cause of acute cervical lymphadenopathy.

6. The most common causative pathogens of acute bacterial cervical lymphadenitis are Group B Streptococcus.

7. Atypical mycobacterial, or non-tuberculous mycobacterial infection, often affects older children above the age of five years.

8. The most common cause of chronic cervical lymphadenopathy is malignancy.

9. Worrying features of lymphadenopathy secondary to malignancy include firm, indurated, fixed and matted lymph nodes that are usually not tender.

10. To diagnose Kawasaki disease, fever must always be present with the full constellation of symptoms, including polymorphous exanthem, bilateral non-suppurative conjunctivitis, changes in lips and oral mucosa, changes in extremities and unilateral cervical lymphadenopathy.

11. Kikuchi-Fujimoto disease is an uncommon, self-limiting illness that never leads to any significant complications.

12. Targeted investigations should be performed for a child with cervical lymphadenopathy if the clinical assessment is suggestive of a serious underlying aetiology.

13. In subacute or chronic cervical lymphadenopathy, full blood count and C-reactive protein test are appropriate first-line investigations.

14. Thrombocytosis might be present in cases of reactive cervical lymphadenitis or inflammatory conditions such as Kawasaki Disease.

15. Mediastinal widening on chest radiography is not a feature that might be seen in children with lymphoma.

16. The gold standard for tissue diagnosis for cervical lymphadenopathy is an excisional biopsy.

17. Most cases of isolated cervical lymphadenopathy are reactive in nature and resolve in 4-6 weeks.

18. Toxic-looking children as well as children with features of Kawasaki disease should be immediately referred to the emergency department.

19. Oral Augmentin is not an appropriate first-line antibiotic for outpatient treatment.

20. A child who has been started on oral antibiotics in the outpatient setting should be re-evaluated 48-72 hours later for clinical response.

\begin{tabular}{|c|c|}
\hline True & False \\
\hline$\square$ & $\square$ \\
\hline$\square$ & $\square$ \\
\hline$\square$ & $\square$ \\
\hline$\square$ & $\square$ \\
\hline$\square$ & $\square$ \\
\hline$\square$ & $\square$ \\
\hline$\square$ & $\square$ \\
\hline$\square$ & $\square$ \\
\hline$\square$ & $\square$ \\
\hline$\square$ & $\square$ \\
\hline$\square$ & $\square$ \\
\hline$\square$ & $\square$ \\
\hline$\square$ & $\square$ \\
\hline$\square$ & $\square$ \\
\hline$\square$ & $\square$ \\
\hline$\square$ & $\square$ \\
\hline$\square$ & $\square$ \\
\hline$\square$ & $\square$ \\
\hline$\square$ & $\square$ \\
\hline$\square$ & $\square$ \\
\hline
\end{tabular}

\section{Doctor's particulars:}

Name in full:

MCR no.:

Specialty:

Email:

\section{SUBMISSION INSTRUCTIONS}

Visit the SMJ website: http://www.smj.org.sg/current-issue and select the appropriate quiz. You will be redirected to the SMA login page.

For SMA member: (1) Log in with your username and password (if you do not know your password, please click on 'Forgot your password?'). (2) Select your answers for each quiz and click 'Submit'.

For non-SMA member: (1) Create an SMJ CME account or log in with your SMJ CME username and password (for returning users). (2) Make payment of SGD 21.40 (inclusive of $7 \%$ GST) via PayPal to access this month's quizzes. (3) Select your answers for each quiz and click 'Submit'.

RESULTS:

(1) Answers will be published online in the SMJ January 2021 issue. (2) The MCR numbers of successful candidates will be posted online at the SMJ website by 11 January 2021. (3) Passing mark is $60 \%$. No mark will be deducted for incorrect answers. (4) The SMJ editorial office will submit the list of successful candidates to the Singapore Medical Council.

(5) One CME point is awarded for successful candidates. (6) SMC credits CME points according to the month of publication of the CME article (i.e. points awarded for a quiz published in the November 2020 issue will be credited for the month of November 2020, even if the deadline is in January 2021).

Deadline for submission (November 2020 SMJ 3B CME programme): 12 noon, 4 January 2021. 